\title{
Experimental evaluation of factors that affect the time of permanence of a user in a news website in Colombia
}

\section{Evaluación experimental de factores que afectan el tiempo de permanencia de un lector en un portal web de noticias en Colombia}

\author{
Nini Johanna Rodríguez Álvarez ${ }^{\text {a }}$ \\ https://orcid.org/0000-0002-5812-321X
}

\author{
Eduardo Javier Pedraza Caro ${ }^{b}$ \\ https://orcid.org/0000-0002-8067-7489
}

Ray Alfredo Bello Dávila
https://orcid.org/0000-0003-1187-9009

Ricardo Fernando Otero-Caicedo ${ }^{d}$

https://orcid.org/0000-0002-0358-8538

Pontificia Universidad Javeriana, Bogotá, Colombia

${ }^{a}$ rodriguez.nini@javeriana.edu.co

${ }^{b}$ eduardo.pedraza@javeriana.edu.co

cr.bello@javeriana.edu.co

dr.otero@javeriana.edu.co

\section{ABSTRACT}

News websites are a digital extension of newspapers whose purpose is to meet the needs of their visitors in terms of news and information. In these sites, the time a reader remains consuming content is important because a large part of its income is obtained from advertising guidelines. In the present study, it was evaluated how the type of reading device, the presence of multimedia content and the length of the articles, affect the permanence of the readers in the site. Using a sample of paid subscribers from a business news web portal, three experiments were conducted under different approaches: online, where all users went through different news articles, online, where the news article was the same for all the subjects and an offline made in a reading laboratory. From the analysis of variance, it was determined that the reading device and the presence of multimedia content can influence the time a user stays on the website. In addition, in the local experiment, it was observed that readers feel more comfortable consuming content on devices with larger screens.

Keywords: time of permanence, information portals, reading device, multimedia content, experimental design.

\author{
Recibido e1: 06/03/2019 \\ Aceptado e1: 30/10/2019
}

\section{RESUMEN}

Los portales informativos son una extensión digital de los periódicos cuya finalidad es satisfacer las necesidades de sus audiencias en términos de noticias e información. De manera que, el tiempo que permanece el lector consumiendo contenido es de gran importancia, porque gran parte de sus ingresos se obtienen a partir de pautas publicitarias. En el presente estudio se evaluó cómo el tipo de dispositivo de lectura, la presencia de contenido multimedia y la extensión de los artículos, afectan el tiempo de permanencia de los lectores. Usando una muestra de suscriptores de pago de un portal web de noticias de negocio, se realizaron tres experimentos bajo diferentes enfoques: uno en línea donde todos los usuarios pasaron por todos los tratamientos con diferentes artículos noticioso, el segundo donde el artículo noticioso fue el mismo para los sujetos y otro local realizado en un laboratorio de audiencias. A partir del análisis de varianza se determinó que el dispositivo de lectura y la presencia de contenido multimedia tienen un efecto en el tiempo de permanencia de un usuario en el sitio web. Además, en el experimento local se observó que los lectores se sienten más cómodos consumiendo contenido en dispositivos con pantallas más grandes.

Palabras clave: tiempo de permanencia, portales informativos, dispositivo de lectura, contenido multimedia, diseño experimental. 


\section{INTRODUCTION}

Reading information on websites is a growing trend nowadays, which has acquired a remarkable importance in recent times (Blanco \& Sarasa, 2007). The irruption of the internet has modified the habits of information consumption, which raises questions to the publishers about the strategy related to the way they must present their products in the digital format. The existing technology incorporates a wide range of multimedia possibilities and creates its own language, which sometimes diverges from the printed versions (Yunquera Nieto, 2016). News agencies look for strategies to establish themselves as information providers in the mainstream media supported by a robust technological infrastructure, seeking to catch the reader in their websites (González Clavero, 2016).

Reading a newspaper on the Internet means moving among many elements: headlines, stories, advertisement, videos, photos, graphics and navigating within several layers. To understand if the reader really reads or simply observes is one of the crucial points in the development of news websites (Zambarbieri, Carniglia, \& Robino, 2008). According to Liu (2005), the reading of electronic documents takes a greater time to explore and scan, to locate keywords, having a non-linear and selective reading, while less time is devoted to deepening and concentrated reading.

Digital environments demand new ways of communicating, new formats for the presentation of the audiovisual and written product, new features and qualities of the information. The production of multimedia content such as photo galleries, videos, audios and infographics are elements that can produce journalistic notes in a variety of ways. In some cases, these are considered by readers as a better way to present information (Masip, Micó, \& Meso, 2012). Multimedia elements are currently one of the most visible tools in Latin American digital newspapers (Hernández, 2010).

Written words still occupy a central place among the journalistic contents, because the text still constitutes the basis of important elements in a news article such as the titling and explanation of an event. According to Arias (2016), although digital media grants importance to the creation of content adapted to the web, it still lacks implementing concrete actions to favor its development. Even in printed designs, elements such as title, images or text are channels to express different kind of information (Peñarrieta, Rodríguez \& Ramos, 2014). Current journalism demands professionals, capable of being creative and innovative in the way they deliver the information to the reader, real intermediaries between the reality and the public. emphasizing the use of multimedia gives out the possibility of pioneering in the journalistic tale (Hernández, 2010).

Despite the dramatic changes observed over the past decade in terms of news consumption, the age of digital news is still at a primary stage, as most news content audiences prefer to watch it, instead of reading or listening to it. This was revealed by a Pew Research Center study (Mitchell, Gottfried, Barthel, \& Shearer, 2016), in which the habits of news consumption and the behavior of news audiences on the web were explored. Knowing the changes in the consumption habits of audiences is essential to evaluate the scope and effects of the digital trend and its prospects (Casero-Ripollés, 2012).

Two aspects that focus the search for initiatives by the editors and producers of digital newspapers: how to make audiences consume more content on the website and maintain their role as mediators between information sources and users. The challenge is to look for formulas that allow the loyalty of current readers and attract new audiences, for this, the news newspapers must adopt a more competitive posture against the new journalistic digital cultural imposed formulas, suggesting that the purpose and the quality of the information should be managed and measured. When the portal of information achieves a good position in the search engines, this is considered a measure of quality for the website and it demonstrates how attractive the content displayed turned out to be.

Considering the above, this work intends to perform an exploratory analysis to determine if factors such as the reading device, the length of the articles and the presence of multimedia content, have an influence on the time readers stay on the journalistic notes in a news web portal.

\section{LITERATURE REVIEW}

Nielsen Norman Group (2011) conducted a study on various websites, showing that, on average, users read approximately $25 \%$ of the content exposed, highlighting that websites can hold the 
attention of a reader for much longer periods of time when giving a clear value proposal. Articles with general descriptions, short and simplified pages, but providing the reader with links for a long and deep coverage, tend to be more attractive (Nielsen Jakob, 2007).

In addition, due to the immersion of technology, computers, tablets and cell phones are considered as reading devices. According to the Pew Research Center (Mitchell, Stocking, \& Matsa, 2016) regardless of the variations in screen sizes and interactions associated with the device, news web readers spend more time on long news articles than on short ones.

The interaction between the reader and the information is produced directly with the content. Aspects such as the graphic layout is irrelevant for the decision to read the text. Characteristics associated with visual design such as typography and color are just a way of making the text readable (Vega Pintado, 2014). The source of the news is another relevant element to decide what article to read (Rovira, Capdevila, \& Marcos, 2014).

Mosconi, Porta, \& Ravarelli, (2008) concluded that multimedia and video contributions allow for a better memory and comprehension of the information compared with the textual form. Although users appreciate the textual descriptions, the animations turn out to be more attractive and facilitate the understanding of new and complex topics. Readers often spend more time viewing articles with text and graphics than articles with only text (Holmberg, 2004). Previous research has concluded that the presence and type of photography in a news article, affects the preferences on the articles and the reading times (Zillmann, Knobloch, \& Yu, 2001).

Reading information on a website can be affected by the number of movements required to visualize the complete content of the articles (Zambarbieri et al., 2008). The way in which the information is organized in a website affects the behavior of the user (Piñero \& Ruiz de Maya, 2007), the use of hyperlinks and movements required to find information in different locations of the website affect the reading behavior as well (van Oostendorp \& van Nimwege, 1998).

Other authors (Cowen, Ball, \& Delin, 2002), (Vaughan \& Courage, 2007) have explored the browsing experience for the users on the web, indicating that the user-friendliness of a website is determined by how easy the users can interact with it, facilitating the search of information and content reading in different formats. The convenience of the interaction is presented by the way in which the text is submitted, specially the size and type of the font (Beymer, Russell, \& Orton, 2008).

Reviewing documented literature research where factors such as usability and information architecture are determinants in the behavior and interaction of a user with a website. Similarly, in the literary review, there are no documented studies examining the time, which is influenced by three factors: extension of the text, reading device and multimedia content. This type of metrics allows an evaluation on how relevant the content offered is and how attractive it can be for advertising companies.

Table 1 presents the factors that were studied in the experiments consulted in this literature review:

Tabla 1.

Previous experimental studies

\begin{tabular}{|c|c|c|c|c|}
\hline Article & Factors & Response variable & Population & $\begin{array}{c}\text { Sample } \\
\text { size }\end{array}$ \\
\hline $\begin{array}{l}\text { (van Oostendorp \& van } \\
\text { Nimwege, 1998) }\end{array}$ & $\begin{array}{l}\text { - Location of the information } \\
\text { - Use of hyperlinks }\end{array}$ & $\begin{array}{l}\text { Time required to locate the } \\
\text { information on a web site }\end{array}$ & $\begin{array}{l}\text { Men and women with diverse } \\
\text { experience in the use of } \\
\text { computers }\end{array}$ & 20 \\
\hline (Zillmann et al., 2001) & $\begin{array}{l}\text { - Photography presence } \\
\text { - Type of photography }\end{array}$ & $\begin{array}{l}\text { - Type of article preferred } \\
\text { - Reading time }\end{array}$ & University students & 63 \\
\hline (Cowen et al., 2002) & $\begin{array}{l}\text { - Web page design } \\
\text { - Type of task done in the } \\
\text { webpage }\end{array}$ & $\begin{array}{l}\text { - Time spent during the execution } \\
\text { of the task } \\
\text { - Number of fixings } \\
\text { - Lifespan of the fixing }\end{array}$ & $\begin{array}{l}\text { Men and women between the } \\
\text { age of } 29 \text { and } 49 \text {, with a variety } \\
\text { of professions and occupations }\end{array}$ & 17 \\
\hline (Holmberg, 2004) & $\begin{array}{l}\text { - Presence of graphics with the } \\
\text { text of the article } \\
\text { - Location of the articles in the } \\
\text { newspaper }\end{array}$ & $\begin{array}{l}\text { Visualization density of the } \\
\text { articles } \\
\text { - Time spent on the articles }\end{array}$ & $\begin{array}{l}\text { Men and women between the } \\
\text { age of } 21 \text { and } 56\end{array}$ & 12 \\
\hline
\end{tabular}




\begin{tabular}{|c|c|c|c|c|}
\hline $\begin{array}{l}\text { (Beymer, Orton, \& } \\
\text { Russell, 2007) }\end{array}$ & $\begin{array}{l}\text { - Presence of an image in a } \\
\text { story text } \\
\text { - Type of image that comes } \\
\text { along with the text }\end{array}$ & $\begin{array}{l}\text { - Reading speed. } \\
\text { - Regression rate } \\
\text { - Amount of material re-read } \\
\text { - Withholding rate } \\
\end{array}$ & $\begin{array}{l}\text { Men and women employed in an } \\
\text { IT company }\end{array}$ & 82 \\
\hline $\begin{array}{l}\text { (Zambarbieri et al., } \\
\text { 2008) }\end{array}$ & $\begin{array}{l}\text { - Amount of movements } \\
\text { required to visualize the } \\
\text { home page's content } \\
\text { - Amount of movements } \\
\text { required to visualize the } \\
\text { content of an article } \\
\text { - Newspaper editorial }\end{array}$ & Average fixation lifespan. & Men and women web surfers & 14 \\
\hline (Bernal, 2008) & $\begin{array}{l}\text { Used formats for the news } \\
\text { presentations }\end{array}$ & $\begin{array}{l}\text { Valuation of the way the news was } \\
\text { presented }\end{array}$ & $\begin{array}{l}\text { Students between the ages of } 20 \\
\text { and } 22 \text { who are frequent news } \\
\text { consumers }\end{array}$ & 54 \\
\hline (Mosconi et al., 2008) & $\begin{array}{l}\text { - Presentation format of the } \\
\text { news } \\
\text { - Location of the multimedia } \\
\text { links } \\
\text { - Presence of publicity banners }\end{array}$ & $\begin{array}{l}\text { - Amount of news' details that } \\
\text { were remembered } \\
\text { - Time spent between the } \\
\text { beginning of the search activity } \\
\text { and the first time the eye } \\
\text { anchors the multimedia link } \\
\text { - Time spent between the first } \\
\text { time the eye anchors the } \\
\text { multimedia link and the } \\
\text { respective link is opened } \\
\text { Number of banners seen and } \\
\text { remembered }\end{array}$ & $\begin{array}{l}\text { Men and women between the } \\
\text { ages of } 20 \text { and } 40 \text { with } \\
\text { computational ability }\end{array}$ & 30 \\
\hline (Beymer et al., 2008) & $\begin{array}{l}\text { - Font size } \\
\text { - Type of font }\end{array}$ & $\begin{array}{l}\text { - Reading speedy } \\
\text { - Amount of re-read material } \\
\text { - Fixation lifespan } \\
\text { - Withholding rate }\end{array}$ & $\begin{array}{l}\text { Men and women between the } \\
\text { ages of } 20 \text { and } 63\end{array}$ & 82 \\
\hline $\begin{array}{l}\text { (González \& } \\
\text { Velásquez, 2012) }\end{array}$ & $\begin{array}{l}\text { - Layout and presentation of } \\
\text { the objects in the webpage } \\
\text { - Location of the objects in the } \\
\text { webpage }\end{array}$ & $\begin{array}{l}\text { - Permanence of each user in the } \\
\text { objects of each page } \\
\text { - Weighted time of continuance in } \\
\text { - Number of objects that capture } \\
\text { most of the attention to the users }\end{array}$ & $\begin{array}{l}\text { Men and women with an } \\
\text { average of } 24 \text { years of age, with } \\
\text { diverse experience levels in the } \\
\text { browsing of websites. }\end{array}$ & 33 \\
\hline $\begin{array}{l}\text { (Lestari, Hardianto, \& } \\
\text { Hidayanto, 2014) }\end{array}$ & $\begin{array}{l}\text { - Type of web design: } \\
\text { adaptive and responsive } \\
\text { - Type of browsing device: } \\
\text { desktop or mobile phone }\end{array}$ & $\begin{array}{l}\text { - Number of scrolls required to } \\
\text { navigate the home page } \\
\text { completely in a web site } \\
\text { - Number of movements required } \\
\text { to search an article in a website } \\
\text { - Number of clicks required in the } \\
\text { search of an article in a website }\end{array}$ & $\begin{array}{l}\text { Students from the University of } \\
\text { Indonesia familiarized with web } \\
\text { browsing on mobile phones }\end{array}$ & 156 \\
\hline (Fortanet, 2017) & $\begin{array}{l}\text { - Design of a website for a } \\
\text { mobile version } \\
\text { - Location of the news } \\
\text { - Textual content } \\
\text { - Multimedia content } \\
\text { - Typography }\end{array}$ & $\begin{array}{l}\text { - Time of permanence in the } \\
\text { website } \\
\text { - Abandonment rate of a website } \\
\text { - Fixation density } \\
\text { - Length of the fixation } \\
\text { - Number of fixations }\end{array}$ & $\begin{array}{l}\text { Men and women from diverse } \\
\text { professions and occupations }\end{array}$ & 62 \\
\hline $\begin{array}{l}\text { (Jiménez, Aguilar, } \\
\text { Sánchez Gómez, \& } \\
\text { Montoro Gutiérrez, } \\
\text { 2018) }\end{array}$ & $\begin{array}{l}\text { Route of the assigned task that } \\
\text { the user needed to perform in a } \\
\text { webpage: a simple or extensive } \\
\text { task }\end{array}$ & $\begin{array}{l}\text { - User satisfaction valuation } \\
\text { - Number of clicks required to } \\
\text { finish the task } \\
\text { - Time the users spent to complete } \\
\text { the tasks }\end{array}$ & $\begin{array}{l}\text { Men and women between the } \\
\text { ages of } 18 \text { and } 64 \text {, with a } \\
\text { esecondary or superior education }\end{array}$ & 45 \\
\hline
\end{tabular}

Source: authors.

Unlike the studies reviewed, the present research seeks to analyze, the influence of the reading device, the presence of multimedia content and the length of the articles as factors contributing to the time of permanence in a portal web. In addition, unlike other studies, the selected sample corresponds to current paid subscribers of the news portal.

\section{CONTEXT}

The website selected to conduct the experiment is a Colombian digital diary, leader on information related to economic and business news. This portal offers information about the economy in Colombia and the world, about companies, business and financial affairs. The news articles in each edition 
are focused on tracking businesses with news bookmarking, the economic endeavor of the country, and global markets. This includes trends in different sector opportunities such as finance, infrastructure, health, transportation, mines and energy, internal and external commerce, market values, agricultural activities, macro-economy and housing, among others.

The information architecture of the web site is composed of nine sections, and the design of the page is adaptive, meaning that the appearance of the webpages can be adjusted to the reading device (laptop, smartphone, tablet) which makes the navigation experience easier for users. The audience of the portal is a specialized one, who searches for updated news on the economics as well as the analytical opinion of experts on market indicators. The users in the current database are part of the Colombian high economical class, specifically high educated males.

\section{METHODOLOGY}

For the present study, three experiments were conducted in 2018, each one aiming to explore the effect of the factors mentioned above in the time a reader spends in a news portal, varying the conditions of the experimentation, such as the environment when reading, the amount of treatments applied to each reader, the order when accessing the trial websites and the devise chosen for reading. In each experiment the users were given the links of the trial webpage they should join, with different articles and a series of combinations in the length of the article and presence of multimedia content. The statistical model applied for the three experiments was a $2^{3}$ fixed factors design. The factors that were studied are presented in table 2 .

\section{Table 2}

Factors studied in the experiment

\begin{tabular}{|c|c|c|c|}
\hline Factor & $\begin{array}{l}\text { Factor } \\
\text { description }\end{array}$ & $\begin{array}{l}\text { - level } \\
\text { factor }\end{array}$ & + level factor \\
\hline $\mathrm{A}$ & Reading device & Computer & Smartphone \\
\hline B & $\begin{array}{l}\text { Length of the } \\
\text { article }\end{array}$ & $\begin{array}{l}\text { About } 300 \\
\text { words }\end{array}$ & $\begin{array}{l}\text { About } 500 \\
\text { words }\end{array}$ \\
\hline $\mathrm{C}$ & $\begin{array}{l}\text { Presence of } \\
\text { multimedia } \\
\text { content }\end{array}$ & Just text & $\begin{array}{l}\text { Presence of } \\
\text { multimedia } \\
\text { content }\end{array}$ \\
\hline
\end{tabular}

Source: authors.

To summon up the participation in each experiment, an invitation was sent to a random sample of current subscribers who pay for the content in the news webpage. Since the users could accept or reject participating in the experiment, the sample was not purely random, instead, the characteristics of the users who did not accept the invitation were analyzed to guarantee they did not have significant differences with the ones who accepted it.

For the development of the investigation, a trial version of a news webpage was used and fed with news articles produced in the last two weeks. Four different versions were used for the webpage trial with the following characteristics: The first website had short articles, the second site had long articles, the third one had long articles with multimedia content and the fourth webpage had short articles with multimedia content.

In the first experiment, each reader received an email with eight different links, each link with a different story presented combining the level of factors B and $\mathrm{C}$, four of which had to be accessed from a computer and four others from a smartphone. However, there was no control over environmental conditions and reading time. In the second experiment, a single link to an article was sent by email to a different sample of readers. In this case, the news was the same for all readers, and each of them received it in a single combination of factors B and C. As in the first experiment, there was no control of the reading device or the conditions of the reading environment. In the third experiment, the tests were conducted in a hearing laboratory to have control over the reading environment. In addition, all the readers went through all the combinations of the levels of factors A, B and C. In all experiments, the invited users were offered an incentive for their participation in the test. Hereunder, the characteristics of each experiment are summarized.

Table 3.

General characteristics of each experiment

\begin{tabular}{|c|c|c|c|c|c|}
\hline $\begin{array}{c}\text { Data } \\
\text { collection }\end{array}$ & $\begin{array}{c}\text { ¿The } \\
\text { subjects } \\
\text { completed } \\
\text { all the } \\
\text { treatments? }\end{array}$ & $\begin{array}{c}\text { ¿Where } \\
\text { the articles } \\
\text { the same } \\
\text { between } \\
\text { treatment? }\end{array}$ & $\begin{array}{l}\text { Treatments } \\
\text { by subject }\end{array}$ & $\begin{array}{c}\text { Incentive } \\
\text { to } \\
\text { participate } \\
\text { in the test }\end{array}$ & Modality \\
\hline $\begin{array}{c}\text { First } \\
\text { experiment }\end{array}$ & $\begin{array}{c}\text { Yes, from } \\
\text { B, C }\end{array}$ & No & 4 & Yes & Online \\
\hline $\begin{array}{c}\text { Second } \\
\text { experiment }\end{array}$ & No & Yes & 1 & Yes & Online \\
\hline $\begin{array}{c}\text { Third } \\
\text { experiment }\end{array}$ & $\begin{array}{c}\text { Yes, } \\
\text { Froom A, } \\
\text { B, C }\end{array}$ & No & 8 & Yes & Local \\
\hline
\end{tabular}

Source: authors. 
The data from the experiments were captured in real time through the Chartbeat tool. In order to capture the data of the tests, a tag was associated to the test version of the website, which allowed to register the users' interactions with the trial webpage.

\section{STATISTICAL MODEL}

The statistical model used for the three experiments is a $2^{3}$ fixed factor design. For each experiment, a previous descriptive analysis of the data was made. Having this information, a verification of assumptions such as normality and homogeneity of variances was made. ANOVA variance analysis was performed to evaluate the influence of the navigation device, the length of the article and the presence of the multimedia content with the time the person stays in the news page.

\section{RESULTS}

\subsection{First Experiment}

In the first experiment 8 trial websites were used, each site was fed with different news, and a combination of the articles with variable lengths and the presence of multimedia content. The time of permanence began when the user clicked on the address of the indicated site and ended when the user left the site. A random sample of 700 registered users was selected, located in several cities and municipalities of Colombia, who accessed the portal between 3 and 4 times per week in the last quarter.

An invitation was sent by email to a selected group of users to read the news of their interest, they were told, they had to access 4 test sites from their computer and 4 other websites from a smartphone. Each email indicates the allocation of the access order suggestion to each test website for the 700 users who were invited to participate in the experiment.

The order in which the test sites were placed in the emails was not the same for all users. Of the 700 users that were invited, only 161 agreed to participate in the test. Each user who participated in the test was granted an incentive.

\subsubsection{Statistical Description}

In the first experiment, 161 users participated and a general average of 6.54 minutes of permanence was registered on the website. According to the diagram of means presented in figure 1 , the average behavior of the reader when the news was read in a computer was higher than the general average and when read in mobile device was lower. With this, the time spent in the portal is greater when the site is accessed from a computer and the contents are accompanied by multimedia elements. It was also noted that the time spent in the portal is less when the site is accessed from a mobile device and the content is not accompanied by multimedia elements.
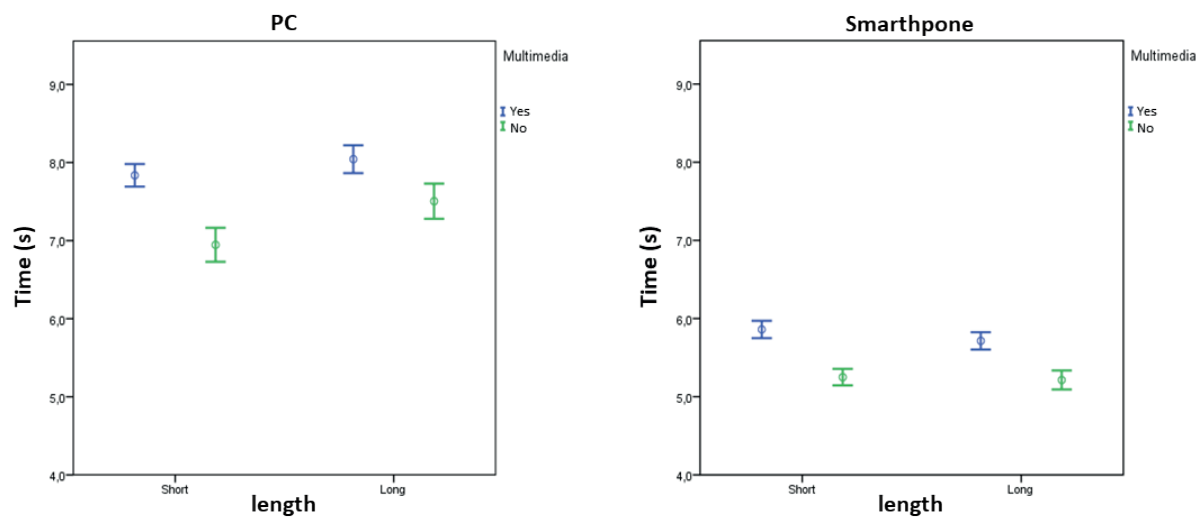

Figure 1. Error bars for the first experiment, factors are the reading device, the length of the article and presence of multimedia content Source: authors.

\subsubsection{ANOVA Assumptions}

To demonstrate the assumption of normality, the Kolmogorov-Smirnov test was used, and the outcome indicated a normal behavior of the residuals with results for the first experiment of 0.12 . To test the assumption of variance homogeneity, the Levene test was used, obtaining 
as a result of the first experiment a significance value of 0.11 . In this way, using a confidence level of 0.95 as a reference, we concluded that the data behaved according to the assumptions in order to apply the ANOVA statistical test.

\subsubsection{Statistical Test}

Analysis of variance corresponding to the statistical test is presented in table 4 , in which there are 3 factors: reading device, length of the article and presence of multimedia content, each with two levels and the user as a block.

Table 4.

ANOVA for the first experiment

\begin{tabular}{lccccc}
\hline Origin & Sum of squares & $\begin{array}{c}\text { Degrees of } \\
\text { Freedom }\end{array}$ & Mean Square & F & Significance \\
\hline User (Blockage) & 429.879 & 160 & 2.687 & 3.369 & .001 \\
Device & 1383.093 & 1 & 1383.093 & 1734.160 & .000 \\
Length & 6.846 & 1 & 6.846 & 8.583 & .003 \\
Multimedia & 129.686 & 1 & 129.686 & 162.604 & .000 \\
Device * Length & 18.103 & 1 & 18.103 & 22.699 & .000 \\
Device * Multimedia & 2.027 & 1 & 2.027 & 2.542 & .111 \\
Length * Multimedia & 4.263 & 1 & 4.263 & 5.345 & .027 \\
Device * Length * & 1.175 & 1 & 1.175 & 1.473 & .225 \\
Multimedia & 893.28 & 1120 & .798 & & \\
Error & 2868.35 & 1287 & & & \\
Total & & & & & \\
Sourc: & & & &
\end{tabular}

Source: authors.

According to the ANOVA table, the device, the length of the article, the presence of multimedia content, the interaction between the type of device and the length of the article and the interaction between the length of the article and the presence of the multimedia content are related to the time spent by the reader in a webpage.

\subsection{Second Experiment}

In the second experiment, 4 trial websites were used, unlike the first experiment, each site was fed with the same news article, but with a different combination of article length and presence of multimedia content. The time of permanence began when the user clicked on the address of the site and ended when the user left the site. In the second experiment, a random sample of 1000 registered users were selected, located in several cities and municipalities of Colombia, and they accessed the portal between 3 and 4 times a week in the last quarter.

An email inviting the selected users was sent for reading the news, for which they were told they should access a single test website from a reading device of their choice. In this experiment out of 1000 users who were invited only 165 agreed to participate in the test. Table 6 shows the characteristics of the test websites that were sent to the users who were invited to participate.

Table 5

Trial websites sent to the users according to the experiment

\begin{tabular}{cl}
\hline $\begin{array}{c}\text { Number of } \\
\text { users }\end{array}$ & \multicolumn{1}{c}{ Characteristics of the trial website } \\
\hline 250 & $\begin{array}{l}\text { First trial website: fed with short articles } \\
\text { without multimedia content }\end{array}$ \\
250 & $\begin{array}{l}\text { Second trial website: fed by long articles } \\
\text { without multimedia content }\end{array}$ \\
250 & $\begin{array}{l}\text { Third trial website: fed by long articles } \\
\text { accompanied by multimedia content }\end{array}$ \\
250 & $\begin{array}{l}\text { Fourth trial website: fed by short articles } \\
\text { accompanied by multimedia content }\end{array}$ \\
\hline
\end{tabular}

Source: authors.

\subsubsection{Descriptive Statistics}

In the second experiment, 166 users participated and a general average of 6.60 minutes of permanence was registered on the website. In the means diagram presented in figure 2 , the reading time is greater when the device used is a computer. Due to the above, it can be perceived that the time of permanence of a user in the portal is greater when accessing from a computer. 

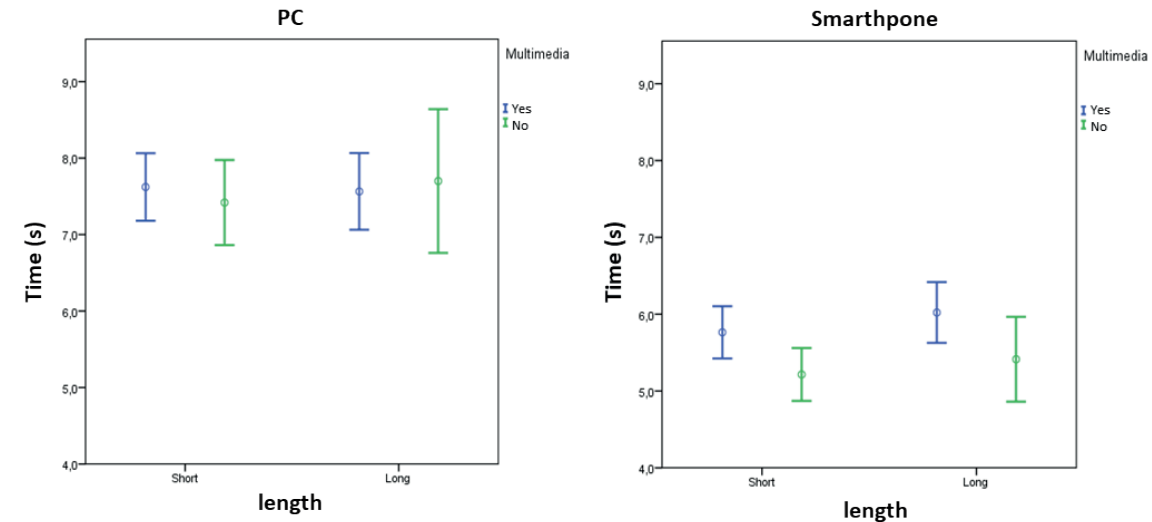

Figure 2. Means diagram for the second experiment, factors are the reading device, length of the article and presence of the multimedia content Source: authors

\subsubsection{Assumptions Trial}

To demonstrate the assumption of normality, the Kolmogorov-Smirnov test was used, the results of which indicated a normal behavior of the residuals with results for the second experiment of 0.24 . To test the assumption of variance homogeneity, the Levene test was used and obtained as a result of the second experiment with a significance value of
0.17 . In this way, using a confidence level of 0.95 as a reference, it can be concluded that the data behaved according to the assumptions in order to apply the ANOVA statistical test.

\subsubsection{Statistical Test}

Table 6 presents the ANOVA table corresponding to the statistical test for the second experiment.

Table 6.

ANOVA for the second experiment

\begin{tabular}{llllll} 
Dependent variable: & Time & & & \\
Origin & $\begin{array}{l}\text { Sums of } \\
\text { squares }\end{array}$ & $\begin{array}{l}\text { Degrees of } \\
\text { freedom }\end{array}$ & $\begin{array}{l}\text { Mean } \\
\text { Square }\end{array}$ & F & Significance \\
\hline Device & 151.459 & 1 & 151.459 & 134.172 & .000 \\
Length & 1.122 & 1 & 1.122 & .994 & .320 \\
Multimedia & 3.649 & 1 & 3.649 & 3.233 & .074 \\
Device * Length & .132 & 1 & .132 & .117 & .733 \\
Device* Multimedia & 2.890 & 1 & 2.890 & 2.560 & .112 \\
Length * Multimedia & .191 & 1 & .191 & .169 & .682 \\
Device * Length* & .387 & 1 & .387 & .343 & .559 \\
Multimedia & .77 .228 & 157 & 1.129 & & \\
Error & 7534.990 & 165 & & & \\
Total & & & & & \\
Source: authors. & & & & &
\end{tabular}

Source: authors.

According to the variance analysis, for this experiment there is only a relationship between the time the person stays in the website and the type of reading device.

\subsection{Third Experiment}

The third experiment was conducted under a controlled reading environment in which 4 trial websites were used, each site was fed with different news and different combination of article length and presence of multimedia content. The experimental subjects were selected from the audience database. The time began when the user clicked on the address of the indicated site and ended when the user left the site. For the third experiment, it was used a random sample of 100 registered users with place of residence in Bogotá D.C. who access the portal between 3 and 4 times a week in the last quarter.

The selected users received an email inviting them to participate in a face-to-face test which took place in a closed area between 9:00 a.m. and 12:00 noon. In this experiment, the environment, and the website content was controlled. The environment 
in which the test took place was the laboratory audience of the Editorial House, which is a space designed to simulate the conditions of a study and an office ambiance, these being the environments in which it is presumed users consume the news. Of the 100 users who were invited to participate in the tests, only 22 users attended.

Before starting the data collection, the content of the trial was explained to each user and they were invited to read the news of interest to them. Then a reading device with internet connection was assigned and a series of links to the trial websites where they should enter in a suggested order for accessing to each trial website.
All users submitted the tests on the same site. A design $2^{3}$ was used with a block factor represented by the reader to avoid the bias derived from the differences between them.

\subsubsection{Descriptive Statistics}

In the third experiment 22 users participated and there was a general average time of permanence of 7.26 minutes. According to the diagram of means presented in figure 3 , the reading time was greater when using the computer as a reading device. On the other hand, a shorter average time was observed when articles were read without the multimedia content in a mobile device.
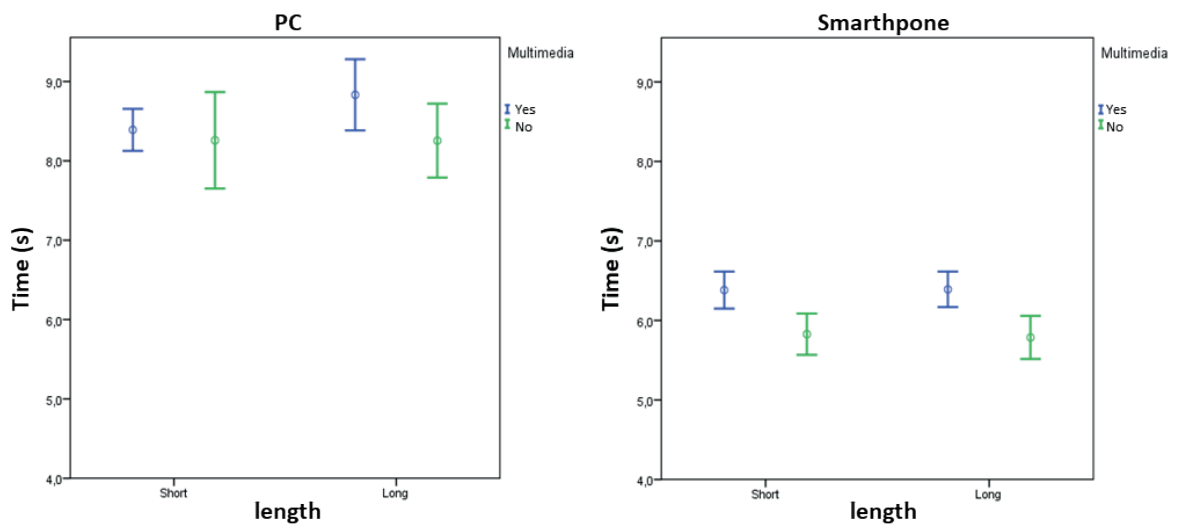

Figure 3. Means diagram for the third experiment, factors are the reading device, length of the article and presence of the multimedia content Source: authors.

\subsubsection{Assumptions Test}

To test the assumption of normality, the Kolmogorov-Smirnov test was used, the results indicated a normal behavior of the residuals with a $p$-value of 0.2 . To test the assumption of variance homogeneity, the Levene test was used, obtaining as a result a p-value of 0.10 . In this way, using a confidence level of 0.95 as a reference, as a conclusion the data behaved according to the assumptions in order to apply the ANOVA statistical test.

\subsubsection{Statistical Trial}

Table 7 presents the results of the variance analysis ANOVA.

Table 7.

ANOVA for the third experiment

\begin{tabular}{lccccc}
\hline \multicolumn{1}{c}{ Origin } & $\begin{array}{c}\text { Sums of } \\
\text { squares }\end{array}$ & $\begin{array}{c}\text { Degrees of } \\
\text { freedom }\end{array}$ & $\begin{array}{c}\text { Mean } \\
\text { Square }\end{array}$ & F & Significance \\
\hline Device & 20.117 & 21 & 1.069 & 1.629 & .049 \\
Length & 240.412 & 1 & 240.412 & 361.885 & .000 \\
Multimedia & .450 & 1 & .450 & .677 & .411 \\
Device * Length & 9.598 & 1 & 9.598 & 14.447 & .000 \\
Device* Multimedia & .603 & 1 & .603 & 0.907 & .342 \\
Length * Multimedia & .557 & 1 & .557 & .838 & .361 \\
Divice* Length * Multimedia & .675 & 1 & .675 & 1.016 & .315 \\
Error & .430 & 1 & .430 & 0.647 & .422 \\
Total & 97.66 & 147 & .659 & & \\
Device & 370.502 & 175 & & &
\end{tabular}


According to the results of the analysis of variance, the type of device and the presence of multimedia content are related to the time spent in the web portal.

\section{RESULTS COMPARISON BETWEEN EXPERIMENTS.}

From the data obtained in the first experiment, reading preference is not given by the usability aspects since the web design is adaptive. This leads to conclude that the choice of the multimedia content consumed in a device is derived from the aspects associated to the reading environment, like speed connection and the device reading characteristics: the size and brightness of the screen, operating system, etc.

The first experiment was not performed in a controlled environment and each user had to read 8 different articles, the influence in the document extent and its double interactions with the presence of multimedia can be related to the fatigue or boredom of completing all of them. In contrast, even though the subjects in experiment 3 were exposed to all treatments, a controlled environment was carried to motivate reading the articles, were the subjects knew they were participating voluntarily in a reading trial, resulting that, the length of the article was not significant. Similarly, the users in experiment 2 only accessed to one article, leading to no presence of fatigue or boredom, resulting that the extension of the article was not significant.

In the three experiments the type of device influenced significantly in the time of permanence, when the reading was made on a desktop, the mean time of stay was higher. Also, the presence of multimedia content was significant in experiments 1 and 3, whereas in experiment 2 its p-value was 0.074 , meaning that it was not that far from the minimum significance level. In all cases, the presence of multimedia content increased the time of permanence in the portal.

\section{CONCLUSIONS}

In this study, from the development of the three experimental designs, the influence of the reading device, presence of multimedia content and reading extension of the article was evaluated in terms of the total time the reader spends in a news webpage. In each experiment, different external factors were evaluated such as the reading environment, thematical content of the articles and the differences of the readers.

The results demonstrated that the type of device used by the reader is associated to the time spent in the webpage, were computers incentivized staying for longer time than the mobile devices. According to what was observed in experiment 3, this is associated with the position when using the computer, which is mainly sitting down, producing a higher reading disposal. In addition, readers demonstrated greater readability on the computer due to its larger screen size.

Furthermore, the presence of multimedia content also affects the time spend in a webpage, leading to an increase in this result. This implies that the readers do assign part of the reading time to these types of contents.

It is observed that the average time of experiment 3 is greater than the other two. This happens because it was done in an environment that motivates people to read. However, in experiment 1 was carried out in a daily environment, and it is observed that when reading from a computer, the time spent reading long articles is greater compared to when using a smartphone. In addition, the dwell time is much longer when a long article is accompanied by multimedia material.

To deepen the results of this study it is recommended to continue with the analysis of other factors that may affect the time spent on the website such as: the personalization of content, the origin of the traffic users who arrive at the website, among others. Similarly, it is suggested to try different levels of text lengths to analyze their relationship with the time spent in the web portal.

\section{CONFLICT OF INTERESTS}

The authors declare no conflict of interest.

\section{ACKNOWLEDGEMENT}

This study was supported by the Industrial Engineering Department in the Pontifical Xaverian University. We thank the entire engineering faculty for its support during the investigation. 


\section{BIBLIOGRAPHIC REFERENCES}

Arias, F. (2016). Teoría y práctica del lenguaje ciberperiodístico. Revista Mediterránea de Comunicación, 7(2), 177-194.

Bernal,A. (2008). Preferencias de la información en Internet. Una nueva propuesta metodológica, ensayada con un grupo de universitarios. Revista Latina de Comunicación Social, 11(63), 189-2019.

Beymer, D., Orton, P. Z., \& Russell, D. M. (2007). An eye tracking study of how pictures influence online reading. IFIP Conference on Human-Computer Interaction, 456-460.

Beymer, D., Russell, D., \& Orton, P. (2008). An eye tracking study of how font size and type influence online reading. Proceedings of the 22nd British HCI Group Annual Conference on People and Computers: Culture, Creativity, Interaction, 2, 15-18.

Blanco, C., \& Sarasa, R. (2007). Análisis de los factores determinantes del interés hacia los periódicos digitales. Conocimiento, Innovación y Emprendedores: Camino Al Futuro, 1844-1858.

Casero-Ripollés, A. (2012). Beyond newspapers: News consumption among young people in the digital era. Comunicar, 20(39), 151-158.

Cowen, L., Ball, L. J., \& Delin, J. (2002). An eye movement analysis of web-page usability. Springer-Verlag Ltd., (1), 1-14.

Fortanet, C. (2017). Estudio experimental del diseño de noticias en smartphones. El caso de El País digital. Universidad de Alicante.

González Clavero, M. V. (2016). Agencias de noticias, su constante reinvención como estrategia para enfrentar la competencia, 22, 329-341.

González, L., \& Velásquez, J. (2012). Una aplicación de herramientas de Eye-Tracking para analizar las preferencias de contenido de los usuarios de sitios web. Revista de Ingeniería de Sistemas, 95-118.

Hernández, T. (2010). Evolución de los principales periódicos digitales latinoamericanos de información general desde comienzos del tercer milenio (2000-2007): caso: Argentina, Chile, Colombia, México y Venezuela. Universidad Complutense de Madrid.

Holmberg, N. (2004). Eye-Movement Patterns in Disabled Readers at Two Age Levels: A Test of Bakker's Balance Model. Journal of Clinical Neuropsychology, 6(3), 241-256.

Jiménez, L., Aguilar, C., Sánchez Gómez, L.,
\& Montoro Gutiérrez, M. P. (2018). User experience and the media: The three-click rule on newspaper websites for smartphones. Revista Latina de Comunicación Social, 73, 595-613.

Lestari, D. M., Hardianto, D., \& Hidayanto, A. N. (2014). Analysis of User Experience Quality on Responsive Web Design from its Informative Perspective. International Journal of Software Engineering and Its Applications, 8(5), 53-62.

Liu, Z. (2005). Reading behavior in the digital environment: Changes in reading behavior over the past ten years. Journal of Documentation, 61(6), 700-712.

Masip, P., Micó, J., \& Meso, K. (2012). Periodismo multimedia en España. Análisis de los contenidos multimedia en la prensa digital. III Congreso Internacional de La Asociación Española de Investigación de La Comunicación.

Mitchell, A., Gottfried, J., Barthel, M., \& Shearer, E. (2016). The Modern News Consumer. Pew Research Center. Retrieved from http://www. journalism.org/2016/07/07/the-modernnews-consumer/

Mitchell, A., Stocking, G., \& Matsa, K. E. (2016). Long-Form Reading Shows Signs of Life in Our Mobile News World. Pew Research Center. Retrieved from http:// www.journalism.org/2016/05/05/long-formreading-shows-signs-of-life-in-our-mobilenews-world/

Mosconi, M., Porta, M., \& Ravarelli,A. (2008). OnLine Newspapers and Multimedia Content: an Eye Tracking Study. Proceedings of the 26th Annual ACM International Conference on Design of Communication, 55-64.

Nielsen, J. (2011). How Long Do Users Stay on Web Pages? Nielsen Norman Group. Retrieved from https://www.nngroup.com/articles/howlong-do-users-stay-on-web-pages/

Nielsen Jakob. (2007). Long vs. Short Articles as Content Strategy. Nilsen Norman Group. Retrieved from https://www.nngroup.com/ articles/content-strategy-long-vs-short/

Peñarrieta, L., Rodríguez, L., \& Ramos, K. (2014). Análisis de los contenidos de elementos impresos de la portada de diario correo edición región Puno 2012. Revista Comunic@cción. ISNN 2219-7168. 5(2), 59-65.

Piñero, M., \& Ruiz de Maya, S. (2007). La organización de la información de un sitio web: efectos en el consumidor. Revista 
Española de Investigación de Marketing, ISSN 1138-1442, 11(2), 89-116.

Rovira, C., Capdevila, J., \& Marcos, M. (2014). La importancia de las fuentes en la selección de artículos de prensa en línea: un estudio de Google Noticias mediante seguimiento ocular (Eye-Tracking). Investigación Bibliotecológica, 28(63), 15-28.

van Oostendorp, H., \& van Nimwege, C. (1998). Locating Information in an Online Newspaper. Journal of Computer-Mediated Communication, 4(1).

Vaughan, M., \& Courage, C. (2007). SIG: Capturing Longitudinal Usability: What Really Affects User Performance over Time? In CHI '07 Extended Abstracts on Human Factors in Computing Systems (pp. 21492152). New York, NY, USA: ACM.
Vega Pintado, E. (2014). La mirada interactiva. De la gráfica de la interacción impresa a la edición de contenidos. ICONO14, 12, 212-243.

Yunquera Nieto, J. (2016). Revistas y diarios digitales en España. Historia de una evolución (Primera Ed). Barcelona.

Zambarbieri, D., Carniglia, E., \& Robino, C. (2008). Eye Tracking Analysis in Reading Online Newspapers. Journal of Eye Movement, 2(4), 1-8. Retrieved from http://e-tracking.unipv.it/ eye/publication/JEMR 2008.pdf

Zillmann, D., Knobloch, S., \& Yu, H. S. (2001). Effects of Photographs on the Selective Reading of News Reports. Media Psychology, 3(4), 301-324. 